\title{
Ontogenetic and Phylogenetic Allometry (Bivariate and Multivariate) for Young Morphologists
}

\author{
Alometría Ontogenética y Filogenética (Bivariada y Multivariada) para Jóvenes Morfólogos
}

Carlos Alberto Mandarim-de-Lacerda ${ }^{1}$

MANDARIM-DE-LACERDA, C.A. Ontogenetic and phylogenetic allometry (bivariate and multivariate) for young morphologists. Int. J. Morphol., 37(2):466-472, 2019.

SUMMARY: The current young morphologist has a background in cellular and molecular biology, where the production of knowledge is very intense and rapid. However, as demonstrated in this review, quantitative methods in morphology, especially allometry, may be significant in demonstrating relationships between size and shape, ontogeny, and phylogeny. These themes are essential to the morphologist and should not be neglected because it improves the morphologists capacity for criticism and proposing projects. In this text, both ontogenetic and phylogenetic allometries in bivariate and multivariate studies are commented. Therefore, it is an initial text for those who have not yet been introduced to the topic, which gives the basis for being increased in the future, with more specific literature.

KEY WORDS: Scaling; Evolution; Slope; Growth; Principal components analysis.

\section{INTRODUCTION}

A mathematical relationship between the shape and size of an anatomical structure (animal or plant) is called allometry $($ Gr. allos $=$ another + Gr. metron $=$ measure $)$. Allometric relationships can be determined during development (ontogenetic allometry) or in mature individuals throughout the process of evolution of a species (phylogenetic allometry) (Pilbeam \& Gould, 1974).

Allometry (or scaling) is the study of the interdependence of size and shape (or function). Changes in the body size of a living being are inevitably linked to changes in morphological and physiological variables to maintain the best adapted to the environment governed by the laws of physics. Allometric methods and models are used to describe these changes quantitatively. If allometric relations are known, it is possible to forecast (within certain limits) the values of the biological variables of an organism for giving body size (Jürgens, 1991) (Fig. 1).

It is impressive how the allometric method has been used to answer the most varied questions in biology, evolution, and medicine. A quick search in Pubmed (December 2018) using the keyword allometr* found 6120 published articles. There are studies with plants (Niklas, 2004), mitochondrial function (Miettinen \& Bjorklund,
2017), genetics (Winter \& Brooks, 2007), human evolution (Corruccini \& Ciochon, 1979; Berge, 1998; Rosas \& Bastir, 2004), animal evolution (Berge \& Penin, 2004; Baliga \& Mehta, 2018), physiology (Atanasov, 2007), pharmacology (Mandarim-de-Lacerda \& Pereira, 2001; Ahlawat \& Srinivas, 2008), cardiology (Li, 2018), obstetrics (Mandarim-deLacerda \& Boasquevisque, 1993), pediatrics (Mahmood, 2016), dentistry (Deloison \& Fenart, 1997; Polychronis \& Halazonetis, 2014), and many other applications.

Nevertheless, the biomedical and biological students (including medicine and dentistry) are usually no longer challenged with quantitative morphology concepts and possibilities (including allometry), as they are overburdened with the rich recent knowledge produced in the cell and molecular biology. However, we must also encourage the use of quantitative methods by students and researchers as this increases their capacity for criticism and investigation. In a recent paper, we discuss the procedures of quantitative morphology using morphometry and stereology (Mandarim-de-Lacerda \& del Sol, 2017), complemented here with allometry.

The unforgettable professor Henri Pineau introduced me to allometry and studies on growth (UFR Biomédicale 


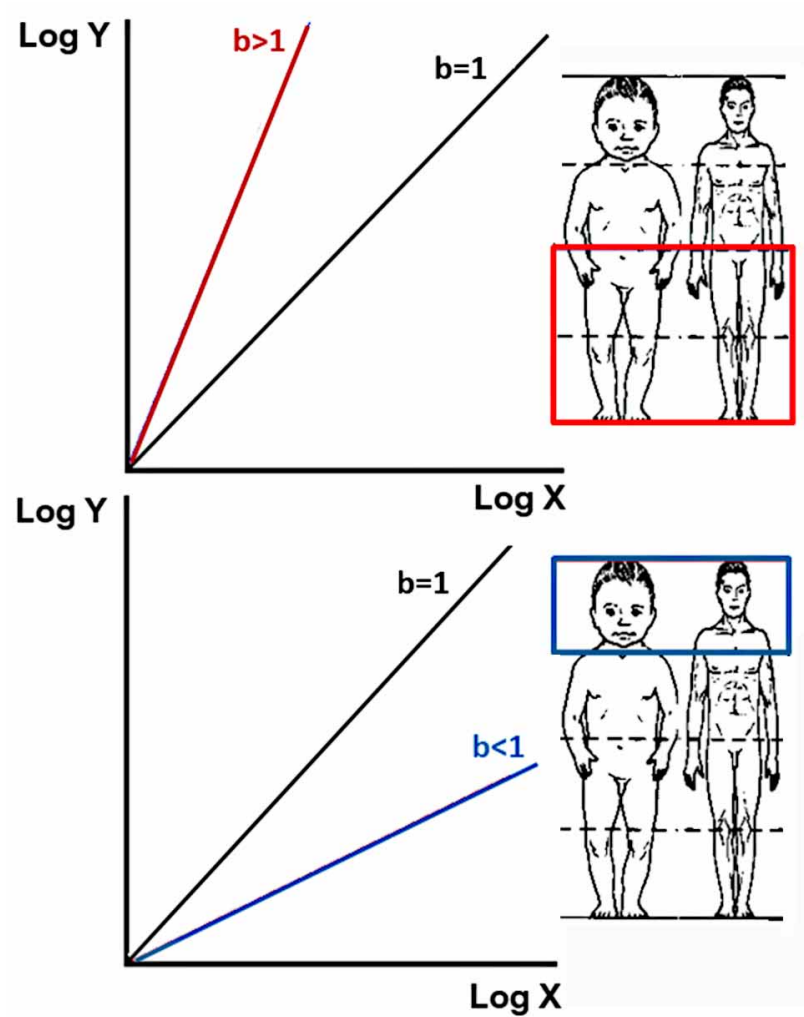

Fig. 1 - Allometry measures the relationship between size and shape as well as the differential growth rates of the parts of a living organism's body. At the top (positive allometry, red) we see that the ratio of leg length to height increases from $40 \%$ in the child to $55 \%$ of the adult. At the bottom (negative allometry, blue) the ratio of face height to height decreases from $25 \%$ in the child to $15 \%$ of the adult.

des Saints-Pères, Faculté de Médicine, Université René Descartes) after reading his thesis "Growth and its laws" (la croissance et ses lois) (Pineau, 1965) and enjoying his easy conversation on the many afternoons when he came to my office to taste Brazilian coffee (which I always had). Monsieur Pineau helped me with calculations and interpretations during the writing of my thesis (Mandarimde-Lacerda, 1985).

In allometric studies, the first decision is to choose the mathematical model that fits the data. Linear and nonlinear models have been proposed, discussed and used (or rejected) for both practical and theoretical reasons (German \& Meyers, 1989a). Some mathematical models (e.g., high-order polynomial equations) can adjust the data appropriately but have coefficients practically impossible to interpret biologically (German \& Meyers, 1989b).

We shall see below that the standard equation for examining the relationship between $\mathrm{Y}$ and $\mathrm{X}$ variables is the Huxley log-transformed model (Stevens, 2009), which is a linear model that assumes that the growth rate of the dependent variable $\mathrm{Y}$, relative to the independent variable $\mathrm{X}$, is measured by the coefficient $\mathrm{b}$ (slope) (German \& Meyers, 1989a).

There is no solid theoretical basis for the successful use of Huxleys empirical model. However, some arguments support the Huxleys concept of "multiplicative growth," and the method of log-transformation in growth studies has been usual in analyzing specific or multiplicative growth (Katz, 1980; Shea, 1985; Jolicoeur, 1989).

Allometric relationships are considered specific for a structure in a given species (animal or plant) during development or in adult life. Thus, they are relevant to differentiate or, on the contrary, establish similarities between anatomical structures homologous or analogous to different individuals. So, we can use the allometric coefficient in mathematical-statistical methods of multivariate analysis, such as discriminant analysis (Torres et al., 2010).

The allometric equation is empirical and has been employed since the late 19th century studying "the dependence of the brain weight on the body weight and mental abilities" (Die Abhängigkeit des Hirngewichts von dem Körpergewicht und den geistigen Fähigkeiten) (Snell, 1892). However, it was with the British scientists D'Arcy Thompson (Thompson, 1917) and Julian Huxley (Huxley, 1932) that the method spread (Gould, 1966).

The allometric equations must be accompanied by a statistical study stating the significance and confidence interval (necessary to better interpret the biological meaning of the allometric research). Therefore, the limits of use of the allometric equations would be (Schmidt-Nielsen, 1985):

a. The equations are descriptive (they are not biological laws);

b. They are useful to show how much a quantitative variable is related to the size of the body;

c. The equations can reveal principles and correlations that would otherwise be obscure;

d. They are useful as a basis for comparison and may show deviations from a pattern;

e. The equations are helpful in estimating expected values of a variable, or organ, or function, related to body size;

f. They cannot be used for extrapolations outside the limits of the data for which they were determined. 


\section{Bivariate allometry}

The power function (parabola equation) [equation \#1] or its log-transformation [equation \#2] is used in bivariate allometric studies. In logarithmic form, it represents the firstdegree equation that represents a line. For this reason, some authors consider the log transformation preferable because it is easier to interpret (but the results are strictly the same using both equations). The log transformation of the variables can use the neperian logarithm (natural) or any other logarithm (the base 10, for example; at least three decimal places is recommended working with $\log$ ).

$$
\begin{gathered}
Y=a X^{b} \\
\log Y=\log a+b \log \mathrm{X}
\end{gathered}
$$

In the bivariate study (also said univariate), the abscissa $\mathrm{X}$ is the independent variable, and the ordinate $\mathrm{Y}$ is the dependent variable. The allometric coefficient $b$, the slope, represents the specific rate of change of $\mathrm{Y}$ and $\mathrm{X}$. In growth studies (ontogeny) the coefficient a (or $\log$ a) is considered the "initial growth coefficient" (Teissier, 1948) (Fig. 2).

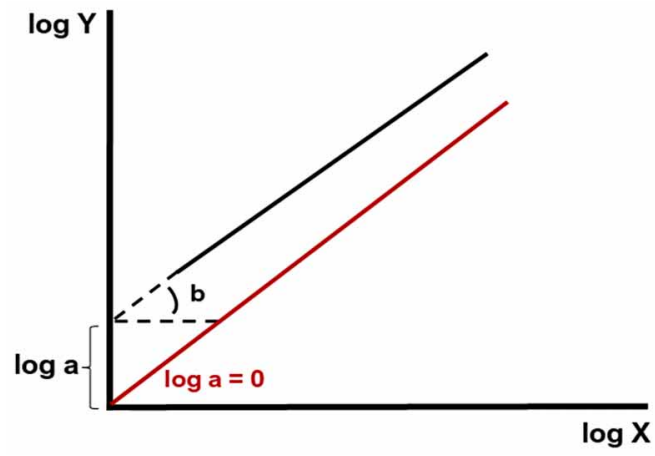

Fig. 2.- Still analyzing the allometry with log-transformed data $(\log \mathrm{Y}=\log \mathrm{a}+\mathrm{b} \log \mathrm{X})$. We see that the angular coefficient $\mathrm{b}$ (also called the allometric coefficient) represents the slope. The point where the line would touch the Y-axis is measured by log a, and if $\log a=0$ the line passes through the origin of the axes.

The representation of these equations is a parabolic segment [equation \#1, Fig. 3] or a line segment [equation \#2, Fig. 4].

When $b=1$ there is an isometry (the maintenance of the geometric similarity with the increase of the shape of the structure -- the shape is maintained with increasing size). When $b<1$ (negative allometry), the ratio $\mathrm{Y} / \mathrm{X}$ decreases with the absolute magnitude increase of $X$. When $b>1$ (positive allometry), there is a differential increase of $Y$ relative to $X$ (Figs. 1 and 4). However, we emphasize that the use of this criterion to indicate allometry or isometry is only valid when the dimensions of $\mathrm{Y}$ and $\mathrm{X}$ are the same. In other situations, the rules for allometry (positive or negative) and isometry may vary (as detailed in Table I).
Table I. Isometry conditions (*).

\begin{tabular}{llc}
\hline $\mathbf{Y}$ & $\mathbf{X}$ & Isometry (b) \\
\hline $\mathrm{mm}$ & $\mathrm{mm}$ & 1 \\
$\mathrm{~mm}^{2}$ & $\mathrm{~mm}^{2}$ & 1 \\
$\mathrm{~mm}^{3}$ & $\mathrm{~mm}^{3}$ & 1 \\
\hline $\mathrm{mm}$ & $\mathrm{mm}^{2}$ & $1 / 2$ (or 0.50 ) \\
$\mathrm{mm}$ & $\mathrm{mm}^{3}$ & $1 / 3$ (or 0.33 ) \\
$\mathrm{mm}^{2}$ & $\mathrm{~mm}^{3}$ & $2 / 3$ (or 0.67 ) \\
\hline $\mathrm{mm}^{3}$ & $\mathrm{~mm}^{2}$ & 3 \\
$\mathrm{~mm}^{3}$ & $\mathrm{~mm}^{2}$ & $3 / 2$ (or 1.50 ) \\
$\mathrm{mm}^{2}$ & $\mathrm{~mm}$ & 2 \\
\hline & &
\end{tabular}

* The millimeter was used here as an example (it could be whatever unit of length). The mass (which represents a three-dimensional magnitude) can be compared to a cubic length of equal proportions, i.e., gram vs. cubic meter, milligram vs. cubic millimeter.

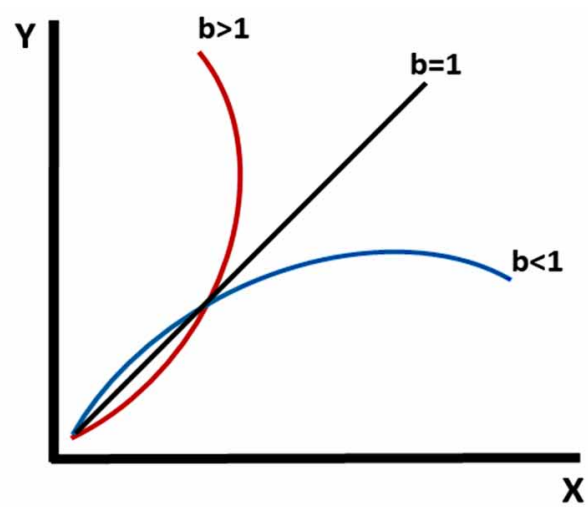

Fig. 3. Example of how allometric curves can be with the equation in the form of power ( $\mathrm{Y}=\mathrm{a} \mathrm{X}^{\mathrm{b}}$ - parabolic segment). Note that positive allometry $(b>1)$ has a left concave curve (red), while negative allometry $(b<1)$ has a right concave curve (blue). When there is an isometry $(b=1)$, the representation is a line (black).

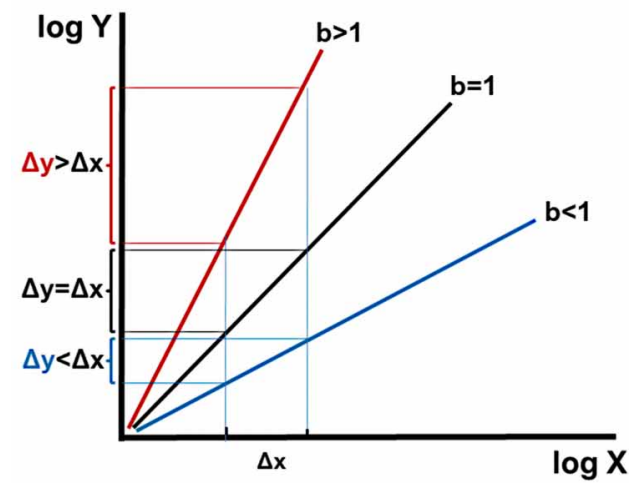

Fig. 4. The graphical representation using log-transformed data and first-degree equation $(\log \mathrm{Y}=\log \mathrm{a}+\mathrm{b} \log \mathrm{X})$. When there is an isometry ( $\mathrm{b}=1$, black line), $\Delta \mathrm{x}$ and $\Delta \mathrm{y}$ are proportional. In positive allometry ( $\mathrm{b}>1$, red line) $\Delta \mathrm{y}$ is more significant than $\Delta \mathrm{x}$, and in negative allometry ( $b<1$, blue line) is the opposite, $\Delta \mathrm{y}$ is smaller than $\Delta \mathrm{x}$.

\section{Fitting the graph}

The graph of the power function, or its log transformation, is usually fit by the least squares method, or type 1 regression (Sokal \& Rohlf, 1995; Kilmer \& Rodriguez, 2017). With log-transformed data, the first-degree equation draws a line and quickly allows calculation of the coefficients 
$\mathrm{a}$ and $\mathrm{b}$ as indicated below (equations \#3 to \#6) (available in the current statistical packages).

$$
\begin{gathered}
a=Y-b X \\
b=\frac{n\left(\sum x y\right)-\left(\sum x\right) \cdot\left(\sum y\right)}{n\left(\sum x^{2}\right)-\left(\sum x\right)^{2}} \\
Y=\frac{\sum y}{n} \\
X=\frac{\sum x}{n}
\end{gathered}
$$

The strength and significance of the correlation between $\mathrm{Y}$ and $\mathrm{X}$ are measured with the Pearson coefficient of correlation (r, equation \#7).

$$
r=\frac{n\left(250 \sum x y\right)-\left(\sum x\right) \cdot\left(\sum y\right)}{\sqrt{\left[n\left(\sum x^{2}\right)-\left(\sum x\right)^{2}\right] \cdot\left[n\left(\sum y^{2}\right)-\left(\sum y\right)^{2}\right]}}
$$

The statistic to verify how much $\mathrm{r}$ differs significantly from zero is available with the t-distribution and n-2 degrees of freedom (equation \#8).

$$
t=\frac{r \sqrt{n-2}}{\sqrt{1-r^{2}}}
$$

However, the biometric variables are subject to measurement errors that may be dependent on the accuracy of the instrument or the observer. Therefore, the type 2 regression method was proposed to overcome this problem with measurements and can be assessed by two main techniques (but there are others):

a. The major (or principal) axis;

b. The reduced (or standardized) major axis.

Generally, no distinction is made with which technique we correct regressions that cannot be considered free of measurement errors (Sokal \& Rohlf, 1995) [the discussion -- which method should be used for type 2 regression -- is irrelevant when the value of $r$ is high (Reiss $\&$ Schmid-Araya, 2010)]. Thus, we suggest the procedure of the reduced major axis (RMA) because of easy calculation.

We can calculate the slope by RMA (now our new allometric coefficient) as the ratio between the slope determined by the least squares method (LSM, already mentioned) and the Pearson correlation coefficient (equation \#9). The more the coefficient $r$ approaches 1, the smaller the difference between the $b_{L S M}$ and $b_{\text {RMA }}$ coefficients. However, correction for the RMA is significant as the coefficient $r$ moves away from the unit.

$$
b_{R M A}=\frac{b_{L S M}}{r}
$$

\section{Comparison between allometric coefficients}

When we have more than one set of data, and we evaluate the allometry in each set, then we must answer the following questions:

a. Is the difference between the allometric coefficients b of each data set statistically significant?

b. The different allometric coefficients b come from the same population?

The answers are given when we compare the slopes $\mathrm{b}$ for different populations (or samples). A simple method to test the hypothesis about the equality of the coefficients $\mathrm{b}$ of two populations (1 and 2) involves the use of t-test (equations \#10 to \#12) with a degree of freedom [(n1 + n2) -4] (Zar, 2010) (most statistical packages can perform the analysis).

$$
t=\frac{\left(b_{1}-b_{2}\right)}{\mathrm{S}_{(\mathrm{b} 1-\mathrm{b} 2)}}
$$

The standard error of the difference of coefficients $\mathrm{b}$ is:

$$
S\left(b_{1}-b_{2}\right)=\sqrt{\left[\frac{S^{2}(Y X) 1}{\left(\sum x^{2}\right) 1}+\frac{S^{2}(Y X) 2}{\left(\sum X^{2}\right) 2}\right.}
$$

Moreover, the conjoint mean square residual is:

$$
S_{(X Y)}^{2}=\frac{\left[n\left(\sum Y^{2}\right) 1+\left(\sum Y^{2}\right) 2\right]}{(n 1-2)+(n 2-2)}
$$

We interpret the results as follows: if the coefficients $\mathrm{b}$ calculated for the two sets of data have no difference, i.e., $\mathrm{b} 1=\mathrm{b} 2$, it means that there is no allometric difference between the two populations (i.e., have the same slope). However, the lines may be at different levels in the graph, indicating that the source populations have different initial growth coefficients (intersections) (Huxley, 1932; Teissier, 1948), which can also be tested statistically (intersection test) (Zar, 2010). 
a. An example of ontogenetic allometry testing slopes: the relative growth of the myocardium was studied in 27 staged human embryos (Carnegie stages). The volume of the myocardium was determined for each embryo [Cavalieri's principle with point-counting planimetry -- see details in (Mandarim-de-Lacerda \& del Sol)]. The volume of the myocardium (variable $\mathrm{Y}$, in cubic millimeters) was correlated to embryonic crown-rump length (CRL, variable $\mathrm{X}$, in millimeters) and age (in days). The bivariate model of allometry was used as $\mathrm{Y}=\mathrm{a} \mathrm{X}^{\mathrm{b}}$. The scatter plot was discontinuous, presenting two trends during the post-somitic period. The first part was composed of embryos staged from stages 15 to 20, and the second part by embryos staged from stages 21 to 23 . The breakpoint between these different trends was found at the level of stage 20 (embryo of $22 \mathrm{~mm}$ CRL and age nearly 52 days). From stages 15 to 20, the growth rate of the myocardium was allometrically negative, and from stages 21 to 23 the growth rate was moderately allometrically positive. The test of slopes demonstrated the two growth rates were statistically different. The differences in growth of the myocardium, at least partially, might be due to the functional circulatory increase in the peripheral vascular bed in correlation to the cardiac hemodynamic demand required at the end of the embryonic period proper (Mandarim-deLacerda, 1991a).

b. Another example: Fetal programming (see Barker et al., 1993; Barker, 2000) is a significant risk factor for noncommunicable diseases of adulthood, including coronary heart disease. Mouse embryos from Stages 16 to 23 (Carnegie) were taken from mothers fed a normal protein (NP) or low protein (LP) diet, and the coronary arteries were studied. Although the LP embryos had lower masses, they had faster heart growth rates when compared with the NP embryos (see Table II for results presentation). The subepicardial plexuses were observed earlier in the NP embryos (Stage 20) than in the LP ones (Stage 22; $P<0.01$ ). Apoptotic nuclei were seen around the aortic peritruncal ring beginning at Stage 18 in the NP and LP embryos. FLK1 (+) (fetal liver kinase 1 = VEGF-r2 or vascular endothelial growth factor receptor 2) cells had a homogeneous distribution in the NP embryos as early as Stage 18, whereas a similar distribution in the LP embryos was only seen at Stages 22 and 23. Maternal protein restriction in mice leads to a delay in the growth of the heart in the embryonic period, modifying the development of the subepicardial peritruncal plexus and the apoptosis in the future coronary orifice region (Silva et al., 2011).

\section{Multivariate allometry}

We may be interested in analyzing allometrically different variables of a population (or sample) simultaneously, and in this case, bivariate allometry cannot be used, but multivariate allometry (Shea, 1985).

The principal components analysis (PCA) is frequently used to study multivariate allometry. The linear combination that corresponds to the most substantial portion of the variability is called the first principal component (PC1). The second principal component (PC2) measures the greatest variability after removal of the $\mathrm{PC} 1$ effect. The calculations involve the extraction of eigenvalues and eigenvectors from correlation or covariance matrices, organized with the numeric data (log-transformed or not) of the variables under study (Manly \& Alberto, 2016).

PCA is a data reduction method. A set of correlated variables is transformed into a small set of uncorrelated variables (called principal components) that measure most of the variability among individuals in the sample. The principal components are linear combinations (weighted averages) of the original variables. PC1 has the most significant variance of this linear combination. The successive principal components $(\mathrm{PC} 2, \ldots . \mathrm{PCn})$ are also substantial and can efficiently replace the original variables (Corruccini, 1983).

Eigenvalues and eigenvectors are mathematical indicators associated with a matrix and are related to the algebra of linear transformations (Longman et al., 1989). The eigenvalues are linked to the number of variables and represent the proportion of total variation contained in each component. The degree of correlation that each variable has with a specific component is given by the vector of correlation coefficients (or covariance). In practice, statistical software frequently may determine eigenvalues and eigenvectors (a computer calculation of eigenvalues and eigenvectors is almost mandatory).

Multivariate isometry exists when all p-dimensions increase with the same rate, which implies that all eigenvalues $p$ are equal ( $p$ is the number of variables under analysis) (Manly \& Alberto, 2016). The multivariate isometry hypothesis should be verified with the $X^{2}$ test (equation \#13), with a degree of freedom $\mathrm{p}-1$. A vector greater $\sqrt{1 / p}$ than indicates positive allometry, otherwise negative allometry (Jungers \& German, 1981):

$$
\text { isometry }=\sqrt{\frac{1}{\mathrm{p}}}
$$

Although there is controversy in literature, the choice for the study with PCA is extracting eigenvalues and eigenvectors of a covariance matrix with log-transformed data (Corruccini \& Henderson, 1978; Mandarim-de-Lacerda, 1991b; Mandarim-de-Lacerda \& Alves, 1992). 
Table II. Linear regressions with comparative growth rates (slopes, calculated by the reduced major axis) using the allometric model (log $\mathrm{Y}=\log \mathrm{a}+\mathrm{b} \log \mathrm{X})$. The condition of the isometry for each analysis is indicated and serves to compare with the slopes of the regressions.

\begin{tabular}{|c|c|c|c|c|c|c|c|c|c|}
\hline \multicolumn{2}{|c|}{ Variable } & \multirow{2}{*}{ Groups } & \multirow{2}{*}{ Intercept (SE) } & \multirow{2}{*}{ Slope (SE) } & \multirow{2}{*}{ Isometry } & \multirow{2}{*}{$\mathrm{r}$} & \multirow{2}{*}{$P$} & \multicolumn{2}{|c|}{ Comparison of the slopes } \\
\hline $\mathrm{X}$ & $\mathrm{Y}$ & & & & & & & t-test & $P$ \\
\hline \multirow{2}{*}{$\begin{array}{c}\mathrm{CRL} \\
(\mathrm{mm}, \log )\end{array}$} & \multirow{4}{*}{$\begin{array}{c}\mathrm{HM} \\
(\mathrm{mg}, \log )\end{array}$} & NP & $-2.04(0.09)$ & $2.50(0.09)$ & \multirow{2}{*}{3} & 0.991 & $<0.0001$ & \multirow{2}{*}{2.13} & \multirow{2}{*}{$<0.0001$} \\
\hline & & LP & $-3.34(0.13)$ & $3.54(0.13)$ & & 0.991 & $<0.0001$ & & \\
\hline \multirow{2}{*}{$\begin{array}{c}\mathrm{BM} \\
(\mathrm{mg}, \log )\end{array}$} & & NP & $-1.47(0.09)$ & $0.98(0.04)$ & \multirow{2}{*}{1} & 0.988 & $<0.0001$ & \multirow{2}{*}{3.47} & \multirow{2}{*}{$<0.0001$} \\
\hline & & LP & $-2.53(0.13)$ & $1.27(0.06)$ & & 0.986 & $<0.0001$ & & \\
\hline
\end{tabular}

Abbreviations: CRL, crow-rump length; BM, body mass; HM, heart mass; NP, Normal Protein offspring; LP, Low Protein offspring; P, probability; SE, standard error of the mean; r, Pearson's coefficient of correlation.

c. An example of multivariate allometry: We studied the morphological significance of the endocardial cushion tissue and ventricular myocardium during cardiac development. Endocardial cushion tissue and ventricular myocardium were quantified by point count planimetry and Cavalieri's method [see details in (Mandarim-de-Lacerda \& del Sol)]. The relative growth of the volume of these structures and the embryonic crown-rump length were studied by multivariate allometry (principal components analysis) with the covariance matrix calculated from natural logarithms of the data. Twenty-seven serially sectioned human embryos were examined, ranging from stage 15 to stage 23 (Paris collection). The relative growth of endocardial cushion tissue, ventricular myocardium, and crown-rump length was discontinuous during the post-somitic period. The first component in principal components analysis measures the overall size and, in the present study, accounts for $88.6 \%$ of the total variance. The $X^{2}$ test checked the growth vector isometry hypothesis, and the differences in growth between cardiac structures and crown-rump length were allometric $(P<0.01)$. Endocardial cushion tissue volume and crownrump length grew with negative allometry during the second month of gestation, while ventricular myocardium volume grew with positive allometry. The findings agree with those researchers who consider that endocardial cushion tissue functions only in causing first cardiac fusion and partitioning, with little influence on the formation of definitive cardiac structures (Mandarim-de-Lacerda, 1991b).

\section{ACKNOWLEDGMENTS}

The author is Titular Member of the Brazilian National Academy of Medicine, and Foreign Associated Member of the French National Academy of Medicine, and is supported by Conselho Nacional de Desenvolvimento Científico e Tecnológico (Brazil) (CNPq, Grant No 302.920/ 2016-1), and Fundação Carlos Chagas Filho de Amparo à Pesquisa do Estado do Rio de Janeiro (Faperj, Grant No E$26 / 202.935 / 2017$ ). These agencies had no interference in the accomplishment and submission of the manuscript.
MANDARIM-DE-LACERDA, C. A. Alometría ontogenética y filogenética (bivariada y multivariada) para jóvenes morfólogos. Int. J. Morphol., 37(2):466-472, 2019.

RESUMEN: El joven morfólogo actual tiene una formación en biología celular y molecular, donde la producción de conocimiento es muy intensa y rápida. Sin embargo, como expusimos en esta revisión, métodos cuantitativos en morfología, en especial la alometría, pueden ser significantes en demostrar relaciones entre el tamaño y la forma, la ontogenia y la filogenia. Estos temas son importantes para el morfólogo y no deben ser descuidados porque mejora la capacidad de crítica y la propuesta de proyectos. En este texto, presentamos la alometría ontogenética y la filogenética, en estudios bivariados y multivariados. Por lo tanto, es un texto inicial para quienes aún no se han introducido al tema y que dará las bases para ser acrescentado en el futuro, con literatura más específica.

PALABRAS CLAVE: Escalamiento; Evolución; Inclinación; Crecimiento; Análisis de componentes principales.

\section{REFERENCES}

Ahlawat, P. \& Srinivas, N. R. Allometric prediction of the human pharmacokinetic parameters for naveglitazar. Eur. J. Drug Metab. Pharmacokinet, 33:187-90, 2008.

Atanasov, A.T. The linear allometric relationship between total metabolic energy per life span and body mass of mammals. Biosystems, 90:22433, 2007.

Baliga, V. B. \& Mehta, R.S. Phylo-allometric analyses showcase the interplay between life-history patterns and phenotypic convergence in cleaner wrasses. Am. Nat., 191:E129-E43, 2018.

Barker, D. J. In utero programming of cardiovascular disease. Theriogenology, 53:555-74, 2000.

Barker, D. J.; Gluckman, P. D.; Godfrey, K. M.; Harding, J. E.; Owens, J. A. \& Robinson, J. S. Fetal nutrition and cardiovascular disease in adult life. Lancet, 341:938-41, 1993.

Berge, C. Heterochronic processes in human evolution: an ontogenetic analysis of the hominid pelvis. Am. J. Phys. Anthropol., 105:441-59, 1998.

Berge, C. \& Penin, X. Ontogenetic allometry, heterochrony, and interspecific differences in the skull of African apes, using tridimensional Procrustes analysis. Am. J. Phys. Anthropol., 124:124-38, 2004.

Corruccini, R. S. Principal components for allometric analysis. Am. J. Phys. Anthropol., 60:451-3, 1983.

Corruccini, R. S. \& Ciochon, R. L. Primate facial allometry and interpretations of australopithecine variation. Nature, 281:62-4, 1979. 
Corruccini, R.S. \& Henderson, A.M. Multivariate dental allometry in primates. Am. J. Phys. Anthropol., 48:205-8, 1978.

Deloison, Y. \& Fenart, R. The use of regression functions for reconstruction of the cutaneous profile, from facial bone elements. Rev. Stomatol. Chir. Maxillofac., 98 Suppl 1:85-8, 1997.

German, R.Z. \& Meyers, L.L. The role of time and size in ontogenetic allometry: I. Review. Growth Dev. Aging, 53:101-6, 1989a.

German, R.Z. \& Meyers, L.L. The role of time and size in ontogenetic allometry: II. An empirical study of human growth. Growth Dev. Aging, 53:107-15, 1989b.

Gould, S.J. Allometry and size in ontogeny and phylogeny. Biol. Rev. Camb. Philos. Soc., 41:587-640, 1966.

Huxley, J.S. Problems of relative growth. New York Dial Press 276, 1932.

Jolicoeur, P. A simplified model for bivariate complex allometry. J. Theor. Biol., 140:41-9, 1989.

Jungers, W. L. \& German, R. Z. Ontogenetic and interspecific skeletal allometry in nonhuman primates: Bivariate versus multivariate analysis. Am. J. Phys. Anthropol., 55:195-202, 1981.

Jürgens, K.D. Allometry as a tool for extrapolation of biological variables. Comp. Biochem. Physiol. A, 100C: 287-90, 1991.

Katz, M. J. Allometry formula: a cellular model. Growth, 44: 89-96, 1980.

Kilmer, J.T. \& Rodriguez, R.L. Ordinary least squares regression is indicated for studies of allometry. J. Evol. Biol., 30:4-12, 2017.

Li, J. K. Cardiovascular allometry: analysis, methodology, and clinical applications. Adv. Exp. Med. Biol., 1065:207-24, 2018.

Longman, R.S.; Cota, A.A.; Holden, R.R. \& Fekken, G.C. A regression equation for the parallel analysis criterion in principal components analysis: mean and 95th percentile eigenvalues. Multivariate Behav. Res., 24:59-69, 1989.

Mahmood, I. Prediction of drug clearance in premature and mature neonates, infants, and children $</=2$ years of age: a comparison of the predictive performance of four allometric models. J. Clin. Pharmacol., 56:733-9, 2016.

Mandarim-de-Lacerda, C.A. Étude morphologique de la crista terminalis : développement chez lembryon humain de la période post-somitique ; morphométrie stéréologique cellulaire et étude macro et microscopique sur le cœur de Papio Erxleben, 1777. Mémoire nº 71, Académie de Paris, UER Biomédicale des Saints-Pères, Laboratoire dAnatomie, Faculté de Médecine. Paris, Université René Descartes Paris V, 1985

Mandarim-de-Lacerda, C. A. Growth allometry of the myocardium in human embryos (from stages 15 to 23). Acta Anat. (Basel), 141:2516, 1991a.

Mandarim-de-Lacerda, C.A. A multivariate analysis of cardiac growth in human embryos: endocardial cushions and ventricular myocardium. Cardiovasc. Res., 25: 855-60, $1991 \mathrm{~b}$.

Mandarim-de-Lacerda, C. A. \& Alves, M. U. Human mandibular prenatal growth: bivariate and multivariate growth allometry comparing different mandibular dimensions. Anat. Embryol. (Berl), 186:53741, 1992.

Mandarim-de-Lacerda, C. A. \& Boasquevisque, E.M. Sonographic quantitative analysis of the heart in the third trimester of gestation. Surg. Radiol. Anat., 15:139-43, 1993.

Mandarim-de-Lacerda, C.A. \& del Sol, M. Tips for studies with quantitative morphology (morphometry and stereology). Int. J. Morphol., 35:1482-94, 2017.

Mandarim-de-Lacerda, C. A. \& Pereira, L. M. Heart biometry and allometry in rats submitted to nitric oxide synthesis blockade and treatment with antihypertensive drugs. Ann. Anat., 183:171-6, 2001.

Manly, B. F. J. \& Alberto, J. N. Multivariate statistical methods. A primer. $4^{\text {th }}$ ed. Boca Raton, Chapman \& Hall, 2016. 253p.

Miettinen, T. P. \& Bjorklund, M. Mitochondrial function and cell size: an allometric relationship. Trends Cell Biol., 27:393-402, 2017.

Niklas, K. J. Plant allometry: is there a grand unifying theory? Biol. Rev. Camb. Philos. Soc., 79:871-89, 2004.
Pilbeam, D. \& Gould, S. J. Size and scaling in human evolution. Science, 186:892-901, 1974.

Pineau, H. La croissance et ses lois. Mémoire $\mathrm{n}^{\circ} 6$ - Académie de Paris, UER Biomédicale des Saints-Pères, Laboratoire dAnatomie, Faculté de Médecine. Paris: Université René Descartes Paris V, 1965.

Polychronis, G. \& Halazonetis, D. J. Shape covariation between the craniofacial complex and first molars in humans. J. Anat., 225:22031,2014

Reiss, J. \& Schmid-Araya, J. M. Life history allometries and production of small fauna. Ecology, 91: 497-507, 2010.

Rosas, A. \& Bastir, M. Geometric morphometric analysis of allometric variation in the mandibular morphology of the hominids of Atapuerca, Sima de los Huesos site. Anat. Rec. A Discov. Mol .Cell. Evol. Biol, 278:551-60, 2004.

Schmidt-Nielsen, K. Scaling: why is animal size so important? Cambridge, University Press 241, 1985.

Shea, B.T. Bivariate and multivariate growth allometry: statistical and biological considerations. J. Zool., 206:367-90, 1985.

Silva, G. O.; Aguila, M. B. \& Mandarim-de-Lacerda, C. A. Insights into coronary artery development in a model of maternal protein restriction in mice. Anat. Rec. (Hoboken), 294:1757-64, 2011.

Snell, O. Die Abhängigkeit des Hirngewichts von dem Körpergewicht und den geistigen Fähigkeiten. Arch. Psychiatr., 23:436-46, 1892.

Sokal, R. R. \& Rohlf, F. J. Biometry. The principles and practice of statistics in biological research, $3^{\text {rd }}$. New York: Freeman 887, 1995.

Stevens, C. F. Darwin and Huxley revisited: the origin of allometry. $J$. Biol., 8:14, 2009.

Teissier, G. La relation dallométrie; sa signification statistique et biologique. Biometrics, 4:14-53, 1948.

Thompson, D.W. On growth and form. Cambridge, University Press 793 , 1917.

Torres, T. S.; Aguila, M. B. \& Mandarim-de-Lacerda, C. A. Rosiglitazone reverses cardiac adverse remodeling (fibrosis and vascularization) in perinatal low protein rat offspring. Pathol. Res. Pract., 206:642-6, 2010.

Winter, E.M. \& Brooks, G.A. From Euclid to molecular biology and gene expression: where now for allometric modeling? Exerc. Sport Sci. Rev., 35:83-5, 2007.

Zar, J. H. 2010. Biostatistical Analysis. $5^{\text {th }}$ ed. Upper Saddle River, Prentice Hall 944.

Corresponding author.

Prof. Dr. Carlos Alberto Mandarim-de-Lacerda

Laboratório de Morfometria, Metabolismo

e Doençca Cardiovascular

Universidade do Estado do Rio de Janeiro

Centro Biomédico, Instituto de Biologia

Av. 28 de Setembro, 87 fds.

Rio de Janeiro, 20551-030 RJ

BRAZIL

EMail: mandarim@uerj.br

URL: www.Immc.uerj.br

Received: 01-01-2019

Accepted: 15-02-2019 